\title{
Penguatan Pengelolaan Ternak Wakaf Hibah Produktif melalui Fermentasi Pakan Ternak sebagai Alternatif Pemberdayaan Santri menuju Pesantren Yatim yang Mandiri
}

\author{
Nihayatu Aslamatis Solekah, Ulfi Kartika Oktaviana \\ Department of Syariah Banking, Faculty of Economic, State of Islamic University Maulana Malik \\ Ibrahim Malang, East Java, Indonesia \\ Street Gajayana 50 Malang \\ nihavatuaslamatiss@yahoo.co.id; Ulfiko@yahoo.com
}

\begin{abstract}
Strengthening of productive wakaf livestock management on Himmatun ayat foundation in the form of goat farming which originally amounted to 31 tail to 80 tails and 2 cattle, given the geographical condition of the cracked city that the land is limestone, the main problem is the availability of feed. Because the managers are orphaned students themselves then the initial get goat grant, a lot of goats are dead. The problem is quite serious is during the rainy season lack of supply of animal feed. In the dry season orphaned santri living herding goats in rain-fed rice fields that are not cultivated because it is a rainfed rice field. Goat and cattle feed in the rainy season is a fermentation of mixed kale leaves, bran and yeast. So there is a symbiosis of mutualism in which the survival of orphaned santri is dependent on the productive grant of goats as well as vice versa. Some potentials that can be empowered to benefit from the social, economic and environmental aspects (1) It is necessary to analyze the feasibility level of goat farm management, especially the fulfillment of animal feed for productive grants, so that the farm will continue to grow so that the boarding school can be independent from the aspect of fulfilling the needs of the orphans living in the pesantren. (2) The need for fermented animal wakaf fermentation training for ophan students so as to create the fulfillment of animal wakaf feed throughout the year. (3) The need for assistance in the management of endowment grants productive goat farming, especially aspects of marketing and buman resources aspects so that it will form the spirit of entrepreneurship oph han students to independently manage wakaf productive grant goat and cattle farms.
\end{abstract}

Keyword: productive wakaf, managerial, independent pesantren.

\section{Pendahuluan}

Wakaf tidak dapat dilepaskan dari perkembangan Islam dan dakwah Islam di Indonesia. Banyak organisasi keagamaan, masjid, pondok pesantren, dan lembaga pendidikan yang berdiri di atas tanah wakaf. Pengelolaan wakaf secara produktif untuk kesejahteraan masyarakat menjadi tuntutan yang tidak bisa dihindari lagi. Apalagi di saat Indonesia berkembang sedang mengalami krisis ekonomi yang memerlukan partisipasi banyak pihak. Oleh karena itu sudah selayaknya umat Islam khususnya, dan masyarakat Indonesia pada umumnya mengapresiasi peraturan perundangan perwakafan tersebut secara 
positif. Hadirnya regulasi tersebut merupakan penyempurnaan dari beberapa peraturan perundangan wakaf yang sudah ada sebelumnya dengan menambah hal-hal baru sebagai upaya pemberdayaan wakaf secara produktif dan professional ${ }^{1}$.

Pondok Pesantren Yatim Indonesia 1 (YAI) merupakan cabang dari Yayasan Himmatun Ayat yang tersebar di seluruh Indonesia bahkan sampai Malaysia. Pada Ponpes YAI Cabang Metatu Gresik ini terdapat pengelolaan Wakaf Hibah Produktif berupa Kambing, Sapi dan Tambak. Meskipun Pesantren cabang ini masih baru dua tahun berjalan namun ada hal sangat menarik dalam pengelolaan wakaf hibah produktif utamanya peternakan kambing. Dari Aspek ekonomi maka peternakan ini merupakan tonggak pemenuhan kebutuhan hidup dari para santri yatim yang ada di ponpes YAI ini. Dari Aspek Pemberdayaan maka peternakan ini merupakan wadah pelatihan leadership dan entrepreneurship bagi para santri yatim dikarenakan seluruh pengelolaannya dikelola oleh santri yatim itu sendiri.

Dari uraian di atas, maka dapat diimplikasikan sebagai berikut:

1. Perlu dilakukan analisis tingkat kelayakan pengelolaan peternakan kambing pada pemenuhan pakan ternak wakaf hibah produktif sehingga permasalahan kekurangan pakan pada musim penghujan bisa diselesaikan.

2. Perlunya pelatihan fermentasi pakan ternak wakaf produktif bagi santri yatim sehingga tercipta pemenuhan pakan ternak wakaf ternak sepanjang tahun.

3. Perlunya pendampingan pengelolaan wakaf hibah produktif peternakan kambing, terutama aspek pemasaran dan aspek sumberdaya manusia yang handal sehingga akan terbentuk jiwa entrepreneurship santri yatim agar secara mandiri mengelola wakaf hibah produktif peternakan kambing dan sapi tersebut.

Berdasarkan fenomena di atas, maka perlu dilakukan penelitian action research dalam rangka penguatan aspek manajerial wakaf hibah produktif sebagai tanggung jawab moral perguruan tinggi dalam rangka pengabdian dan pembenahan masyarakat pesantren.

\section{Alasan Memilih Subyek Dampingan}

Kebutuhan penguatan pengelolaan pakan ternak wakaf produktif Yayasan Himmatun Ayat Pondok Pesantren Yatim Indonesia 1 pada peternakan kambing yang awalnya berjumlah 31 ekor menjadi 80 ekor dan 2 Sapi, kebutuhan ini tentunya hanya tergantung pada ketersediaan pakan mengingat kondisi

\footnotetext{
${ }^{1}$ Nynda Fatmawati Octarina and Muh. Barid Nizaruddin Wajdi, "Human Right, PSK And Justice In Law," VRIJSPRAAK : International Journal of Law 1, no. 1 (October 28, 2017): 82-112, accessed November 2, 2017, http ://socialscience.journal-research.org/index.php/Vrijspraak/article/view/20.

Volume 1, Number 2, November 2017 | 171

Penguatan Pengelolaan Ternak W akaf Hibah Produktif melalui Fermentasi Pakan Ternak sebagai Alternatif Pemberdayaan Santri menuju Pesantren Yatim yang Mandiri
}

Nihayatu A slamatis Solekah, U1fi Kartika Oktaviana 
geografis kota Gresik yang tanahnya merupakan tanah kapur. Dikarenakan pengelolanya adalah santri yatim itu sendiri maka awal-awal mendapatkan hibah kambing, banyak sekali kambing yang mati. Dari 15 ekor ternak wakaf hibah produktif tersebut sekitar 10 kambing yang mati, dan kebanyakan setelah beranak, anak kambingnya yang mati dikarenakan minimnya pengetahuan santri dalam beternak. Problem yang cukup serius adalah pada saat musim hujan kurangnya pasokan pakan ternak. Pada musim kemarau santri yatim tinggal menggembalakan kambingnya di sawah-sawah tadah hujan yang memang tidak digarap karena merupakan sawah tadah hujan. Maka yang tumbuh subur adalah rumput dilahan yang sedemikian luas. Pakan ternak kambing maupun sapi pada musim penghujan adalah fermentasi campuran daun kangkung, bekatul dan ragi. Jadi ada simbiosis mutualisme dimana keberlangsungan hidup santri yatim sangat bergantung pada wakaf hibah produktif ternak kambing demikian pula sebaliknya.

Lokasi Yayasan Himmatun Ayat Ponpes YAI ini cukup strategis dikarenakan terletak di dekat perempatan Metatu Benjeng Gersik. Demikian juga diapit MTsN dan MAN 2 Gresik. Sehingga sangat menguntungkan bagi santri yatim untuk bisa bersekolah ditempat tersebut dan gratis. Sehingga hasil Wakaf Hibah produktifnya digunakan untuk kehidupan santri yatim itu sendiri.

\section{Kondisi Subyek Dampingan Saat Ini dan Kondisi Harapan}

Sejak pertama kali dideklarasikan, dakwah yatim Yayasan Himmatun Ayat memang tak mengenal dimensi waktu dan tempat. Aneka program dan dirancang agar bisa semaksimal mungkin mengemban amanah selaku pedakwah yatim, dengan jangkauan yang lebih luas. Di tengah hingar bingar kesibukan kota industri Gresik, di salah satu sudut kota yang kebetulan dekat akses publik, berdirilah Pondok Yatim Himmatun Ayat Gresik di Metatu tepatnya di Jl. Raya Metatu 15 Benjeng. Kode Pos 61172, Gresik, Jawa Timur

Santri yatim yang ada di pondok pesantren ini kebanyakan dari luar Jawa, seperti Nangro Aceh Darussalam korban Tsunami, Nusa Tenggara Timur, Nusa Tenggara Barat, Sampit Kalimantan Tengah dan lain-lain. Alasan dari Pengasuh Pesantren Yatim Indonesia I ini jika menerima dari Jawa jarang yang mau mukim atau bertempat tinggal di pesantren tersebut. Kebanyakan Santri yang sudah menyelesaikan pendidikannya maka mereka kembali ke asal mereka masing-masing. Hal ini yang menjadikan pondok pesantren ini kesulitan melakukan regenerasi dalam pengelolaan dan peningkatan wakaf dan hibah produktif.

Dengan demikian di lingkungan pondok masih terdapat beberapa potensi yang dapat diberdayakan guna menguntungkan dari aspek sosial, ekonomi dan lingkungannya: 
1. Mubadzir-nya lahan tambak wakaf yang belum dikelola dengan baik dikarenakan kurangnya modal ekonomi dan sumberdaya manusia

2. Kondisi kandang kambing yang memerlukan pengelolaan limbah kotorannya sehingga wakaf ternak kambing itu bisa dibudidayakan dengan baik

3. Perlunya Sumberdaya yang mampu memasarkan hasil ternak kambing wakaf hibah produktif yang dapat meningkatkan nilaiguna ekonomi seperti untuk layanan aqiqah dan idul qurban.

4. Aspek sosial dan pembelajaran kemandirian pada santri dapat diwujudkan melalui pembudidayaan wakaf ternak kambing dan sapi menumbuhkan jiwa wirausaha (enterpreneurship).

5. Pendampingan pemberdayaan pakan ternak melalui fermentasi dikarenakan pada saat musim hujan kesulitan mencari rumput dan menggembalakannya di lahan terbuka.

Adapun dampingan yang diharapkan adalah:

1. Terbangunnya santri yatim yang handal yang mampu mengelola wakaf dan hibah produktif kambing dan sapi.

2. Terpenuhinya pakan ternak kambing wakaf dan hibah produktif disetiap tahun mengingat kota Gresik secara geografis kesulitaan air dan tanahnya merupakan tanah kapur dengan pelatihan fermentasi rumput yang bisa tahan lama untuk pemenuhan pakan selama satu tahun.

3. Terciptanya santri yatim yang mampu memasarkan hasil ternak kambing wakaf hibah produktif yang dapat meningkatkan nilai guna ekonomi seperti untuk layanan aqiqah dan 'idul qurban.

4. Terpenuhinya 'media' pembelajaran kemandirian pada santri yatim dapat diwujudkan melalui pengelolaan wakaf dan hibah produktif ternak sapi dan kambing serta pemanfaat lahan kosong sebagai 'laboratorium' menumbuhkan jiwa kepemimpinan (leadership) dan jiwa wirausaha (enterpreneur).

\section{Paradigma Wakaf Produktif}

Achmad Djunaidi telah menawarkan dua hal yang berkaitan dengan wakaf produktif: Pertama, asas paradigma baru wakaf yang terdiri dariasas keabadian manfaat, asas pertanggungjawaban/ responsibility, asas profesionalitas manajemen serta asas keadilan. Kedua, Aspek-aspek paradigma baru wakaf terdiri dari pembaruan/reformasi pemahaman mengenai wakaf, sistem manajemen pengelolaan yang profesional, sistem manajemen ke-nazhir-an/manajemen sumberdaya insani serta sistem rekrutmen wakif. ${ }^{2}$

2 Achmad Djunaidi, Paradigma Baru Wakaf Di Indonesia (Jakarta: Direktorat Pengembangan Zakat dan Wakaf Depag RI, 2005). 63-85. 


\section{Batasan Wakaf Produktif}

Lahirnya Undang-Undang Nomor 41 Tahun 2004 tentang Wakaf serta Peraturan Pemerintah Nomor 42 tahun 2006 tentang Pelaksanaan Undang-Undang Nomor 41 Tahun 2004 adalah bagian dari semangat memperbarui dan memperluas cakupan objek wakaf dan pengelolaannya agar mendatangkan manfaat yang maksimum. Oleh karena itu, wakaf produktif dianggap sebagai paradigma baru wakaf di Indonesia. Masalahnya adalah, apa yang dimaksud dengan wakaf produktif?.

Dalam ilmu manajemen terdapat satu bidang manajemen yang disebut dengan manajemen produksi/operasi. Operasional atau produksi berarti proses pengubahan/transformasi input menjadi output untuk menambah nilai atau manfaat lebih. Proses produksi berarti proses kegiatan yang berupa: (1) pengubahan fisik (2) memindahkan (3) meminjamkan dan atau (4) menyimpan.

Konsep wakaf produktif pada dasarnya dilandasi oleh ketidakpuasan pihak pemerintah (terutama Kementerian agama) terhadap pengelolaan harta wakaf yang dilakukan oleh para nazbir yang berjalan sekarang ini. Ketidakpuasan tersebut kemudian memicu pemerintah untuk memperbaikinya dengan paradigm wakaf produktif, antara lain dengan membentuk undang-undang tentang wakaf.

Jika dihubungkan antara konsep "produksi" dengan ketidakpuasan pemerintah atas pengelolaan wakaf yang dilakukan oleh para nazhir, definisi wakaf produktif secara terminology adalah transformasi dari pengelolaan wakaf yang alami menjadi pengelolaan wakaf yang professional untuk meningkatkan atau menambah manfaat wakaf.

Meskipun demikian, Sudono Sukirno merumuskan bahwa produktif (kata sifat yang berasal dari kata product) diartikan sebagai proses operasi untuk menghasilkan barang atau jasa yang maksimum dengan modal yang minimum. 3 Dengan demikian, wakaf produktif juga dapat diartikan sebagai proses pengelolaan benda wakaf untuk menghasilkan barang atau jasa yang maksimum dengan modal yang minimum.

\section{Pengelolaan Ternak Wakaf Hibah Produktif}

Keberhasilan suatu usaha peternakan ditentukan oleh tiga faktor yaitu pakan (feeding), bibit unggul (breeding) dan manajemen yang baik. Bibit yang berkualitas baik akan mampu tumbuh dengan cepat akan menghasilkan produk yang optimal. Manajemen pemeliharaan yang tepat akan mendukung keberhasilan suatu usaha Membangun kandang kambing untuk pemeliharaan ternak wakaf produktif seperti membangun rumah tempat tinggal manusia sehingga secara hakekat normatif harus sama. Tujuannya

\footnotetext{
${ }^{3}$ Sadono Sukimo, Pengantar Teori Mikroekonomi (Jakarta: PT Raja Grafindo Persada, 1997).
} 
untuk menciptakan desain kandang bagi kambing yang akan dipelihara agar benar-benar menjadi home sweet home bagi ternak tersebut. ${ }^{4}$

Hartadi et al. menyatakan pakan adalah suatu bahan yang dimakan hewan yang mengandung energi dan zat-zat gizi (atau keduanya) di dalam bahan tersebut. Pakan adalah bahan yang dimakan dan dicerna oleh seekor hewan yang mampu menyajikan unsur hara atau nutrien yang penting untuk perawatan tubuh, pertumbuhan, penggemukan, reproduksi dan produksi. ${ }^{5}$ Bahan pakan dapat dibagi menjadi 2 kelompok yaitu konsentrat dan bahan berserat. Konsentrat serta bahan berserat merupakan komponen atau penyusun ransum. ${ }^{6}$

\section{Metode}

Dalam rangka mengubah kondisi santri yatim Yayasan Himmatun Ayat Pondok Pesantren Yatim Indonesia 1 baik secara sosial, ekonomi dan lingkungan, akan digunakan metode PAR (Participatory Action Research). Metode ini dilakukan untuk memahamkan santri yatim terhadap: (1) Potensi-potensi yang dimiliki dari pengelolaan ternak wakaf hibah produktif; (2) Keinginan-keinginan santri yatim untuk mengatasi kekurangan dan kelemahannya khususnya berkaitan dengan pengelolaan wakaf hibah produktif; (3) menyusun strategi dan metode untuk memecahkan permasalahan pemenuhan pakan ternak wakaf hibah produktif sepanjang tahun dan (4) membantu santri yatim mengatasi, memecahkan, dan menemukan jalan keluar permasalahan dari 3 (tiga) aspek di atas.

Metode action research ini digunakan untuk tidak membuat santri yatim dampingan sebagai obyek, tetapi menjadikannya sebagai subyek penelitian. Santri yatim sendiri yang memahami, menginginkan, dan memecahkan permasalahan yang melilitnya. Posisi peneliti lebih sebagai fasilitator bagi masyarakat untuk mencapai cita-citanya dan memberikan jalan keluar dan merumuskan strategi yang dapat digunakan masyarakat untuk mencari jalan keluar bagi permasalahan mereka. Namun perumusan jalan keluar dan strategi ini tetap melibatkan santri yatim dengan harapan apabila santri yatim mengalami masalah sosial, ekonomi dan lingkungan atau lainnya mereka bisa memecahkan permasalahan mereka sendiri tanpa bantuan orang lain.

Dengan Participatory Action Research (PAR) ini bermanfaat untuk memfasilitasi dan memotivasi agar (1) mereka mampu mengidentifikasi potensi, kekuatan dan kelemahan yang ada pada lingkungan pondok

\footnotetext{
${ }^{4}$ T. Setiawan, T. Arsa, Beternak Kambing Perah Peranakan Ettawa (Jakarta: Pen ebar Swad aya, 2005).

${ }_{5}$ H. S. Reksohadiprodjo A. D. Tillman Hartadi, Tabel Komposisi Pakan Untuk Indonesia (Yogyakarta: Gadjah Mada University Press, 1986).

${ }^{6}$ J. Blakely and D. H. Bade., Ilmu Peternakan (Yogyakarta: Gadjah Mada University Press, 1994).

Volume 1, Number 2, November 2017 | 175

Penguatan Pengelolaan Ternak Wakaf Hibah Produktif melalui Fermentasi Pakan Ternak sebagai Alternatif Pemberdayaan Santri menuju Pesantren Yatim yang Mandiri
} 
ENGAGEMENT

Gurnal Pengabdian Kepada Masyarakat

ISSN : 2579-8375 (Print)

ISSN : 2579-8391 (Online)
This work is licensed under a Creative Commons

Attribution-ShareAlike 4.0 International License. CC BY SA

pesantren utamanya potensi wakaf hibah produktif peternakan kambing dan sapi; (2) mereka mampu mengetahui apa yang harus dilakukan setelah point satu di atas dapat terekam; (3) menyusun strategi dan metode yang tepat untuk memecahkan problematiknya dan (4) menyusun rencana aksi berdasarkan prioritas, dan keberlanjutan program melalui tahapan-tahapan hingga mencapai target yang diharapkan (lihat bagan 1)

Adapun strategi yang digunakan dalam melakukan action research ini adalah menggunakan metode yang dapat digambarkan sebagai berikut:

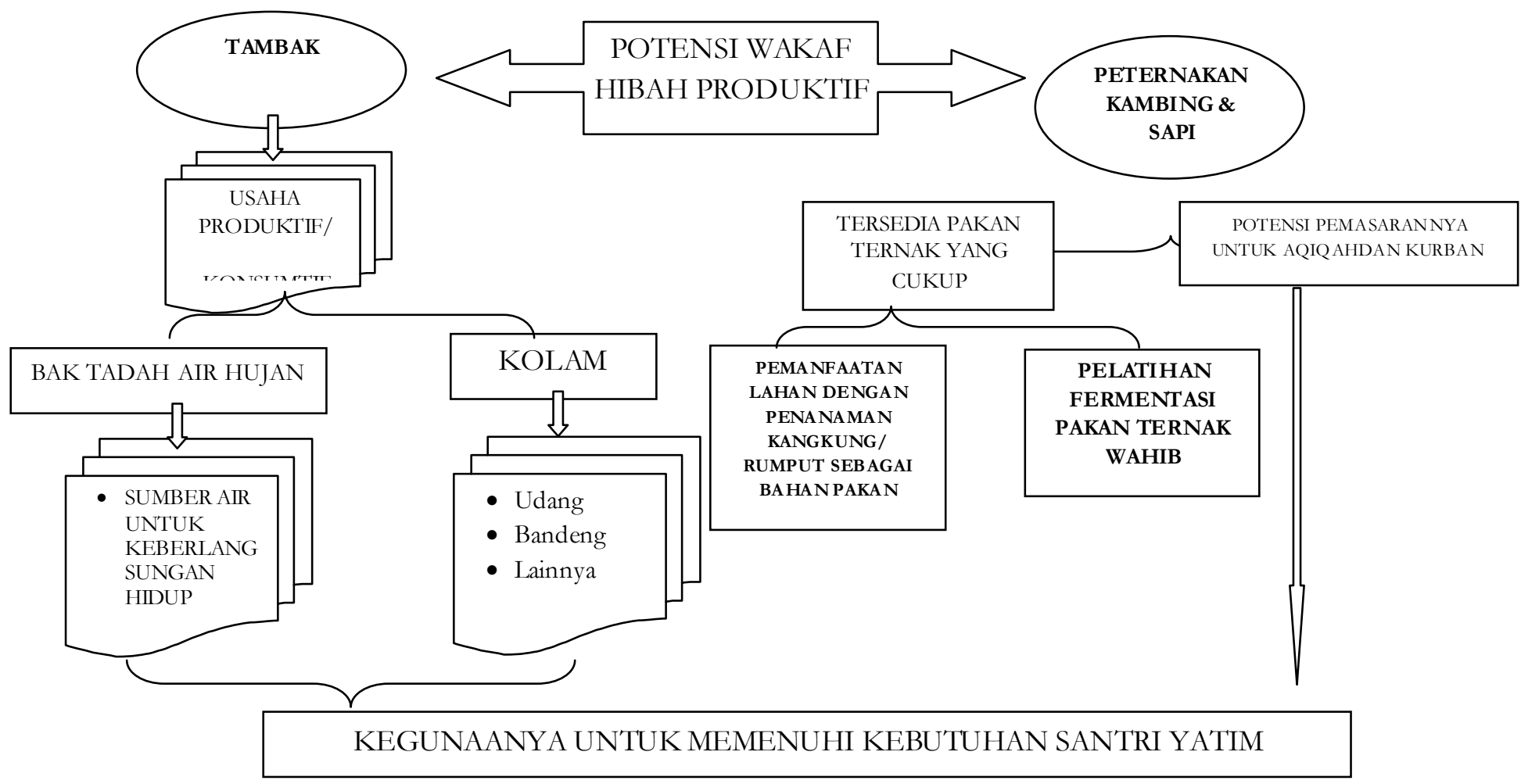

Gambar 1. Mekanisme Kerja PAR Pengelolaan Wakaf Hibah Produktif

Prioritas program ini adalah penguatan pengelolaan pakan ternak wakaf hibah produktif pada peternakan kambing pesantren anak yatim melalui pendampingan pemenuhan pakan ternak dan peningkatan sumberdaya manusia dalam mengelola wakah hibah produktif tersebut yang diambil dalam pelaksanaan program pemanfaatan tambak berdasarkan hasil survey awal dan kesepakatan (agreement) kelompok sasaran dengan pendamping yang telah dilakukan (hasil FGD atau survey awal). 
Dari gambaran proses penelitian action research ini ada empat tahapan dalam melakukan penelitian ini, yaitu:

1. Perencanaan (plan). Perencanaan ini dilakukan setelah memperhatikan kondisi riil di pondok pesantren yatim Indonesia I dengan menggunakan analisis Problem Solving. Berdasarkan prioritas masalah yang dihadapi maka direncanakan akan dilakukan pelatihan fermentasi pakan ternak wakaf hibah produktif

2. Tindakan (action). Setelah proses perencanaan dilakukan, mengimplementasikan rencana yang telah dibuat tersebut dengan dibantu dan difasilitatori oleh peneliti. Tindakan yang dilakukan adalah melalui pelatihan fermentasi pakan ternak wakaf hibah produktif. Selain pelatihan tersebut tindakan lain yang dilakukan adalah pendampingan skill SDM santri yatim dalam mengelola ternak wakaf hibah produktif dalam hal pemberian pakan yang baik dan benar serta menyelesaikan masalahmasalah yang sering dihadapi ternak Wahib tersebut seperti kembung, kutu dan sebagainya. Tindakan lain yang juga dilakukan adalah dengan membuka jaringan pemasaran ternak wakaf hibah produktif seperti untuk hewan Qurban pada hari raya Idul Adha dan Aqiqah.

3. Pengamatan (observe). Pengamatan dilakukan untuk memperhatikan dan menganalisis keberhasilan, kelemahan, dan kekurangan strategi dan metode yang digunakan dalam menyelesaikan problematika pengelolaan ternak wakaf hibah produktif pasca pelatihan fermentasi dan budidaya tanaman kelor sebagai bahan pakan ternak wakaf hibah produktif.

4. Refleksi (reflect). Usaha-usaha yang telah dilakukan dalam memecahkan problematika direfleksikan dan dievaluasi, baik kekurangan, kelemahan, dan keberhasilan strategi dan metode dalam memecahkan problematika pengelolaan ternak wakaf hibah produktif

\section{Hasil dan Pembahasan}

Himmatun Ayat adalah organisasi sosial Islam yang bertujuan membangun kepedulian masyarakat kepada anak-anak yatim dan telantar (AYAT) dalam meraih cita-cita menuju masa depan yang lebih baik. Yayasan ini hadir untuk mengoptimalkan penyaluran dana dari donatur, secara amanah dan profesional dalam memberikan pelayanan terbaik kepada mereka yang membutuhkan.

Dipelopori oleh H. MA. Kholiq Hamid, dr. H. Agus Sukoco dan alumni aktivis masjid kampus berinisiatif untuk mengadakan kegiatan yang dapat menyelamatkan anak-anak yatim dari ancaman putus sekolah. Kegiatan tersebut diberi nama Akbarya (Amal kesejahteraan bagi pelajar yatim) yang mempunyai basecamp di salah satu kamar kos rumah milik orang tua salah satu aktivis. 
Kegiatan yang dilakukan oleh Akbarya awalnya hanya sebatas pengumpulan santunan dari mahasiswa-mahasiswa yang disalurkan dalam bentuk pembinaan dan penyantunan anak yatim usia sekolah di sekitar kampus Universitas Wijaya Kusuma Dukuh Kupang Surabaya. Akan tetapi Setelah setahun berjalan ternyata apresiasi masyarakat sungguh luar biasa dan mendorong pelegalan kegiatan penggalangan ini dalam bentuk sebuah organisasi. Melalui berbagai pertimbangan maka dibentuklah organisasi Himmatun Ayat pada bulan April 2000. Himmatun Ayat kependekan dari Himpunan Muslim Penyantun Anak Yatim, Sesuai namanya, di awal berdiri organisasi ini mempunyai kegiatan yang fokus untuk pembinaan dan penyantunan anak yatim. Namun dalam perkembangannya sasarannya diperluas juga untuk anak telantar.

Sesuai tujuannya membangun kepedulian umat, dalam perjalanannya Himmatun Ayat menjalin kerja sama dengan berbagai pihak baik kelompok masyarakat, lembaga pendidikan hingga instansi-instansi yang bertujuan untuk mendukung dakwah yatim. Dengan sifat keterbukaannya, hingga tahun 2012 ini ada 25 sekretariat cabang telah menjadi bagian dakwah yatim yang tersebar di 10 kabupaten. Sekretariatsekretariat tersebut tersebar dari pusat kota hingga pelosok-pelosok desa dengan total binaan 1.043 anak yatim dan anak telantar dari seluruh penjuru Indonesia. Jumlah ini akan terus berkembang seiring permintaan dari masyarakat untuk bersama-sama membina dan menyantuni anak yatim dan telantar di lingkungan sekitar mereka.

Yayasan Himmatun Ayat mempunyai salah satu anak cabang di kota Gresik tepatnya di Desa Metatu yang didirikan pada tahun 2004. Alasan mendasar yang melatarbelakangi pembukaan cabang ini adalah Bencana tsunami Aceh yang mengakibatkan banyak anak-anak telah kehilangan salah satu bahkan kedua orang tuanya. Pendiri yayasan ini yaitu Bapak H. MA. Kholiq Hamid mempunyai keinginan untuk membawa 5 anak dari Aceh untuk menempuh pendidikan di Pulau Jawa. Desa Metatu tepatnya dimana ada sebuah tanah waqaf tidak termaksimalkan pemakaiannya, dimanfaatkan oleh bapak H. MA. Kholiq Hamid untuk mengasuh dan membimbing ke 5 anak yatim tersebut. Tanah ini merupakan tanah mertua beliau yang diwaqafkan untuk bidang pendidikan khususnya pesantren.

Visi dari Yayasan Himatun Ayat adalah menjadi lembaga peduli anak yatim dan anak terlantar Nasional yang professional prophetic. Sedangkan Misi untuk mencapai visi di atas adalah dengan membina dan menyantuni anak yatim dan anak terlantar (AYAT), berdakwah secara khusus dan fokus pada bidang anak yatim dan terlantar demi kesejahteraan mereka, membawa dakwah yatim ke ranah ilmiah. 


\section{Kendala Pengelolaan Wakaf Hibah Produktif}

Menurut hasil observasi dan wawancara yang kami lakukan pada yayasan Himmatun Ayat Gresik terdapat beberapa kendala dalam Pengelolaan, pemasaran dan Manajemen keuangan.

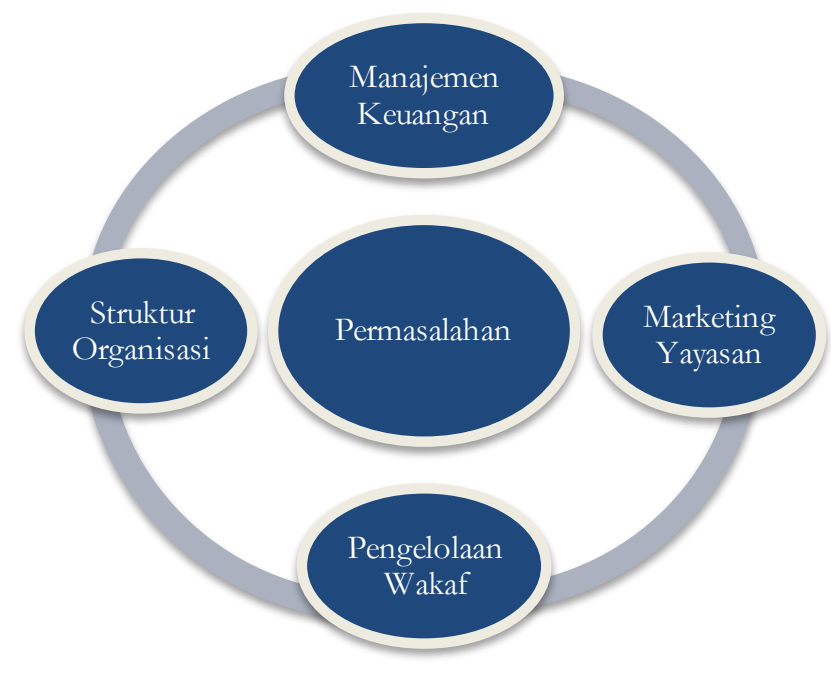

Gambar 2 Kendala yang dihadapi yayasan Himmatun Ayat

\section{Manajemen Keuangan}

Manajemen yang ada dalam yayasan Himmatun Ayat hanya dikelola oleh pengurus inti yakni bapak Kholiq dan ibu Latifah. Pegelolaan keuangan yang berlangsung diolah secara sederhana oleh mereka sehingga belum tersedianya pelaporan keuangan yang jelas di Himmatun Ayat cabang Metatu Kab. Gresik. Manajemen Keuangan yang terjadi sekarang ini masih berupa pencatatan dan perhitungan yang manual tanpa adanya sistem ataupun software yang digunakan.

Minimnya manajemen keuangan di Yayasan ini berdampak pada tidak terlihatnya pandangan yang jelas mengenai dana hasil kegiatan. Padahal pelaporan keuangan yang jelas dapat memberikan kemudahan bagi masyarakat untuk melihat kinerja pengelolaan wakaf di Himmatun Ayat Gresik sehingga berdampak pada ketertarikan dan dorongan masyarakat Muslim sekitar untuk mempercayakan harta wakafnya.

\section{Marketing Yayasan}

Wakaf produktif merupakan pengelolaan yang sangat bermanfaat dan jarang diketahui khususnya di Indonesia. Yayasan Himmatun Ayat merupakan salah satu pengelolan wakaf produktif tersebut. 
Pengelolaan wakaf produktif menjadi keuntungan bagi yayasan ini. Wakaf produktif berupa kambing dan sapi.

Namun, pengelolaan ini tidak dibarengi dengan manajemen pemasaran, sehingga masyarakat sekitar khususnya di wilayah Gresik kurang mengetahui yayasan tersebut. Kendala ini ditunjang dengan lokasi yayasan Himmatun Ayat yang jauh dari pusat Kota Gresik. Dibutahkan marketing yang massive sehingga yayasan yang condong pada pengelolaan wakaf produktif ini dapat dikenal masyarakat.

Pengelolaan dengan minimnya pemasaran mengakibatkan pengelolaan wakaf produktif di yayasan ini kurang berkembang dengan cepat. Hanya dengan mengandalkan promosi mulut ke mulut dan juga data dari pusat mengenai keberadaan yayasan Himmatun Ayat di Gresik, dirasa menjadi salah satu permasalahan yayasan ini belum banyak dikenal masyarakat ${ }^{7}$

\section{Pengelolaan Wakaf Hibah Produktif}

Pengelolaan wakaf Produktif kambing dan sapi dilakukan oleh anak-anak yang menjadi bagian dari yayasan Himmatun Ayat. Pengelolaan wakaf ini dilakukan dari nol, sehingga anak-anak pengelola wakaf belajar secara autodidak. Sapi dan kambing yang dikelola terbilang cukup banyak, namun minimnya fasilitas untuk mengelola makanan menjadi kendala dalam mempercepat proses pembesaran kambing dan sapi.

Selama ini kambing dan sapi yang dikelola makan dari hasil gembala dan juga pengelolaan makan yang sederhana dari anak-anak yayasan. Minimnya mesin pengelolaan ternak menjadi kendala besar dalam pengelolaannya, karena mengolah makanan ini membutuhkan waktu yang cukup lama.

\section{Pendampingan yang Dilakukan dan Perubahan Yang Terjadi}

Setelah mengidentifikasi beberapa potensi yang dimiliki oleh Pesantren Yatim Yayasan Himmatun Ayat Cabang Metatu Gresik serta beberapa permasalahan yang mereka hadapi di dalam mengelola wakaf hibah produktif maka program yang dilakukan adalah:

Penguatan pengelolaan ternak wakaf hibah produktif melalui pelatihan fermentasi pakan ternak. Bentuk dampingan yang dilakukan, dimulai perkenalan dan sosialisasi program maka yang dilakukan

\footnotetext{
7 Arasy Alimudin et al., "The Factors Affecting Land Prices In Housing Location In Sidoarjo Regency," International Journal of Society Development and Engagement 1, no. 1 (2017): 2597-4777.

Volume 1, Number 2, November 2017 | 180 Penguatan Pengelolaan Ternak W akaf Hibah Produktif melalui Fermentasi Pakan Ternak sebagai Alternatif Pemberdayaan Santri menuju Pesantren Yatim yang Mandiri
} 
adalah pemantapan persiapan pemenuhan bahan-bahan yang akan digunakan dalam pelatihan fermentasi pakan ternak wahib dan pencampuran bahan konsentrat sebagai nutrisi ternak wakaf hibah produktif dimulai dengan proses penghancuran bahan-bahan konsentrat. Setelah itu dilakukan pelatihan fermentasi pakan ternak. Materi awal yang diberikan adalah pentingnya aspek pakan dalam usaha peternakan. Dimana bisa ditinjau dari tiga aspek: aspek biologis, aspek ekonomis serta aspek sosial dan lingkungan. Kemudian praktik fermentasi pakan ternak dari bahan-bahan yang ada di sekitar pesantren yatim. Praktik langsung melibatkan santri yatim sehingga mereka bisa memiliki pengalaman dan pemahaman langsung dari praktik tersebut. Perubahan yang terjadi adalah meningkatnya skill santri membuat pakan ternak dari proses fermentasi.

Penguatan skill santri yatim di dalam mengelola ternak wakaf hibah produktif utamanya pada pemberian pakan ternak yang baik dan benar. Bentuk dampingan yang dilakukan adalah dengan memberikan pemahaman dan mencontohkan kepada santri bagaimana pemberian pakan pada ternak: Tujuan pemeliharaan, ternak (Jenis, status fisiologis/bobot badan ternak), zat makanan yang dibutuhkan oleh ternak, bahan pakan dan kandungan zat makanannya, cara meramu pakan, serta cara pemberiannya pada ternak (jumlah dan cara). Perubahan yang terjadi santri mengetahui dengan benar bagaimana memberikan pakan pada ternak dengan baik dan benar, serta santri menjadi faham kesalahan apa yang selama ini mereka lakukan pada pemberikan pakan ternak wakaf hibah produktif.

Penguatan skill santri yatim didalam menyelesaikan masalah-masalah kesehatan ternak wakaf produktif seperti kembung, diare, kudis dan sebagainya. Dari pendampingan yang dilakukan maka ditemukan beberapa penyebab umum yang menjadikan ternak wakaf hibah produktif sakit. Setelah itu diberikan pendampingan langkah-langkah menangani masalah kesehatan ternak tersebut. Perubahan yang terjadi adalah berkurangnya ternak wakaf hibah produktif yang sakit.

Penguatan pasokan bahan pakan ternak wakaf hibah produktif melalui skenario penimbunan bahan pakan saat musim kemarau dimana bahan pakan melimpah dengan menggunakan mesin pencacah rumput sebagai alat sederhana untuk skenario pakan tersebut. Sesuai dengan fokus pada pengabdian ini setelah dilakukan pelatihan fermentasi pakan ternak wakaf hibah produktif guna memenuhi kebutuhan pakan baik pada musim kemarau maupun musim penghujan, maka dibuatlah skenario dengan menyiapkan bahan pakan ternak pada musim kemarau dimana rumput dan bahan baku melimpah, dan dibutuhkan mesin pencacah rumput. Oleh karenanya dilakukan pendampingan penggunaan mesin pencacah rumput. Mesin pencacah rumput untuk ternak wakaf hibah produktif ini memberikan nilai lebih dengan dicacahnya rerumputan yang ada maka rumput tersebut akan lebih mudah dimakan dan dicerna oleh ternak wakaf hibah produktif tersebut. Perubahan yang terjadi adalah kecukupan pakan pada musim hujan setelah pada musim kemarau membuat pakan ternak sebanyak-banyaknya dan di simpan dalam gudang.

Volume 1, Number 2, November 2017 | 181 Penguatan Pengelolaan Ternak Wakaf Hibah Produktif melalui Fermentasi Pakan Ternak sebagai Alternatif Pemberdayaan Santri menuju Pesantren Yatim yang Mandiri 
Penguatan strategi promosi melalui e-marketing, media tulis dan personall selling pada saat hari raya Idul Qurban. Bentuk dampingan yang dilakukan adalah dengan menyebarkan panflet, atau membuat iklan dalam web pesantren YAI 1 tentang jasa penjualan ternak untuk aqiqah atau hewan qurban dan jemput bola dengan membuka gerai penjualan ternak qurban pada hari Raya Idul Adha. Perubahan yang terjadi adalah peningkatan penjualan ternak wakaf hibah produktif tersebut

Secara Berkala menjaga dan memperbaiki sarana dan prasana ternak wakaf hibah produktif sehingga kondisi nya semakin bersih dan layak Sebagai penguat sumberdaya manusia pengelolaan ternak wakaf hibah produktif maka yang dilakukan adalah memberikan semangat dan motivasi melalui penguatan jiwa entrepreneurship pada santri yatim guna menyiapkan mental yang mandiri dan mau meningkatkan skill individu mereka. Sebagai contoh dengan bekerjasama membersihkan kolam air yang merupakan sarana utama kehidupan ternak wakaf hibah produktif. Dikarenakan kolam air ini merupakan sumber kehidupan pesantren hendaknya secara rutin menjaga kebersihan kolam air tersebut, sehingga air yang terdapat di kolam tersebut bisa terjaga kelayakannya untuk pemenuhan konsumsi air ternak wakaf hibah produktif maupun seluruh santri yatim.

\section{Kesimpulan}

Dari beberapa kegiatan yang telah dilakukan maka hasil analisis studi kelayakan pengelolaan ternak wakaf hibah produktif melalui pembuatan alat sederhana untuk proses pembuatan pakan ternak wakaf hibah produktif dalam usaha pemenuhan pakan ternak sehingga peternakan tersebut akan terus berkembang sehingga pondok pesantren tersebut dapat mandiri dari aspek pemenuhan kebutuhan hidup dari anak-anak yatim yang ada di pesantren tersebut dapat dilaksanakan dengan memberdayakan santri yatim tersebut

Pada pelaksanaan pelatihan fermentasi pakan ternak wakaf produktif bagi santri yatim sehingga tercipta pemenuhan pakan ternak wakaf ternak sepanjang tahun dan ditemukan beberapa permasalahan yang biasanya dihadapi dalam pengelolaan ternak wakaf hibah produktif, seperti masalah kesehatan, diserang kutu dan diserang nyamuk atau serangga (caplak) dan diare.

Pada pelaksanaan pendampingan pengelolaan wakaf hibah produktif peternakan kambing, terutama aspek pemasaran dapat dilakukan dengan bekerjasama dengan rumah aqiqah dan qurban sebagai pemasok hewan kurban dan aqiqah, Sementara untuk pendampingan aspek sumberdaya manusia yang handal dilakukan dengan menguatkan motivasi diri sehingga akan terbentuk jiwa entrepreneurship santri yatim agar secara mandiri mengelola wakaf hibah produktif peternakan kambing dan sapi tersebut. 
ENGAGEMENT

Jurnal Pengabdian Kepada Masyarakat

ISSN : 2579-8375 (Print)

ISSN : 2579-8391 (Online)
This work is licensed under a Creative Commons

Attribution-ShareAlike 4.0 International License. CC BY SA 
This work is licensed under a Creative Commons

Attribution-ShareAlike 4.0 International License. CC BY SA

\section{Daftar Referensi}

Alimudin, Arasy, Partomi Simangunsong, Muh Barid, and Nizaruddin Wajdi. "The Factors Affecting Land Prices In Housing Location In Sidoarjo Regency." International Journal of Society Development and Engagement 1, no. 1 (2017): 2597-4777.

Blakely, J., and D. H. Bade. Ilmu Peternakan. Yogyakarta: Gadjah Mada University Press, 1994.

Djunaidi, Achmad. Paradigma Baru Wakaf Di Indonesia. Jakarta: Direktorat Pengembangan Zakat dan Wakaf Depag RI, 2005.

Hartadi, H. S. Reksohadiprodjo A. D. Tillman. Tabel Komposisi Pakan Untuk Indonesia. Yogyakarta: Gadjah Mada University Press, 1986.

Octarina, Nynda Fatmawati, and Muh. Barid Nizaruddin Wajdi. "Human Right, PSK And Justice In Law." VRIJSPRAAK : International Journal of Law 1, no. 1 (October 28, 2017): 82-112. Accessed November 2017.2 http://socialscience.journalresearch.org/index.php/Vrijspraak/article/view/20.

Setiawan, T. Arsa, T. Beternak Kambing Perah Peranakan Ettawa.Jakarta: Penebar Swadaya, 2005.

Sukirno, Sadono. Pengantar Teori Mikroekonomi. Jakarta: PT Raja Grafindo Persada, 1997. 